\title{
EFEKTIVITAS PENGAWASAN PENERAPAN PRINSIP SYARIAH OLEH DEWAN PENGAWAS SYARIAH (DPS) \\ (STUDI KASUS PADA PT. BPRS AMANAH SEJAHTERA) ${ }^{[1]}$
}

\author{
Devika Refgiani \\ Program Studi S1 Ekonomi Islam Fakultas Ekonomi dan Bisnis-Universitas Airlangga \\ Email: drefgiani93@gmail.com \\ Suherman Rosyidi \\ Departemen Ekonomi Syariah-Fakultas Ekonomi dan Bisnis-Universitas Airlangga \\ Email: srosyidi@gmail.com
}

\begin{abstract}
:
This research using qualitative approach while research method used was a case study with using pattern matching technique for analyzing. The analysis is done by looking at the suitability of supervision of the implementation of sharia principle by DPS on BPRS Amanah Sejahtera with SEBI No 15/22/DPbS. The results can be concluded that monitoring of product and new activity by DPS on BPRS Amanah Sejahtera had been in accordance with SEBI NO 15/22/DPbS. The supervision toward activity for raising funds, financing and other services activities by DPS on BPRS Amanah Sejahtera does not satisfy one of the nine points contained in the SEBI No 15/22/DPbS. In general, the supervision by DPS on BPRS Amanah Sejahtera has been effective because DPS not only doing the good supervision but also make improvements and development, DPS monitoring with his best, and DPS give priority to the BPRS Amanah Sejahtera.
\end{abstract}

Keywords: Islamic banks, effectiveness, supervision, sharia principle, Sharia Supervisory Board, regulation of Bank Indonesia.

\section{PENDAHULUAN}

\section{Latar Belakang}

Perbankan syariah muncul karena adanya kesadaran masyarakat muslim untuk menjalankan seluruh aktivitas keuangan sesuai dengan prinsip-prinsip syariah. Pengembangan perbankan syariah di Indonesia dilakukan dalam kerangka dual-banking system (sistem perbankan ganda) untuk menghadirkan jasa perbankan alternatif. Dalam sistem tersebut, perbankan syariah berdampingan dengan perbankan konvensional bekerja secara sinergis dalam mendukung mobilisasi dana masyarakat. Baik perbankan syariah maupun konvensional memiliki fungsi yang sama, yaitu sebagai lembaga intermediasi dalam lalu lintas transaksi kevangan.

Karakteristik perbankan syariah yang beroperasi dengan prinsip bagi hasil merupakan alternatif bagi masyarakat dan bank untuk bekerja dengan saling menguntungkan, saling berbagi risiko, menjunjung keadilan dalam bertransaksi, serta menghindari kegiatan spekulatif dalam melakukan transaksi keuangan. Karakteristik tersebut sesuai dengan prinsip syariah, yaitu sesuai dengan Al-Qur'an dan Al-Hadits. Perbankan syariah diharapkan dapat mendukung stabilitas sistem keuangan secara keseluruhan yang pada gilirannya akan memberikan kontribusi yang signifikan terhadap pencapaian kestabilan ekonomi untuk

\footnotetext{
1] Jurnal ini merupakan bagian dari skripsi yang ditulis oleh Devika Refgiani; NIM: 041211431023 diuji pada 04 April 2016
} 
Refgiani, et al/Jurnal Ekonomi Syariah Teori dan Terapan Vol. 3 No. 9 September 2016: 758-770; Efektivitas Pengawasan Penerapan Prinsip Syariah oleh Dewan Pengawas Syariah (DPS) (Studi Kasus pada PT. BPRS Amanah Sejahtera)

mewujudkan kemaslahatan seluruh mayarakat.

Masyarakat menyambut baik kehadiran lembaga keuangan syariah, terutama masyarakat muslim yang mulai sadar untuk menjalanakan seluruh aktivitas keuangan sesuai dengan prinsip Islam. Berdasarkan penelitian yang dilakukan oleh Patimatu Jahra yang dilakukan di Banjarmasin dengan judul Profil BMT Ukhuwah di Kota Banjarmasin tahun 2002, BMT memiliki peran yang besar bagi pemberdayaan dan pengembangan usaha kecil. Nasabah BMT merasa terbantu oleh pembiayaan untuk menambah modal mereka sehingga usaha mereka semakin meningkat dan kualitas hidupnya pun semakin membaik.

Sebuah penelitian yang dilakukan di Magelang oleh Solihin pada tahun 1999 mendukung penelitian di atas. Penelitian tersebut menyatakan bahwa perbankan syariah mampu menjadi alternatif lembaga keuangan konvensional. Penelitian tersebut menyimpulkan bahwa masyarakat memilih lembaga keuangan syariah karena menerapkan prinsip syariah dan profesionalisme lembaga keuangan syariah sebanding dengan lembaga keuangan konvensional. Dari penelitian ini terungkap bahwa $72 \%$ responden setuju atas keberadaan BMT Kharisma di Kota Magelang.

Sementara itu, tidak semua masyarakat memandang positif kehadiran bank syariah. Hal ini karena terjadinya beberapa kasus yang menimbulkan citra buruk pada lembaga keuangan syariah. Misalnya, di daerah Tegal, penelitian yang dilakukan oleh Ahmad Dahlan pada tahun 2002 yang berjudul Implementasi Pembiayaan Mudharabah di BMT Mentari Bina Artha Tegal menemukan adanya lembaga keuangan syariah yang menerapkan sistem mudharabah muqayyadah fi an-nisbah bi al miyyah dengan perhitungan nisbah yang ditetapkan $2,5 \%$ berdasar jumlah pembiayaan yang dikeluarkan. Mekanisme ini menyerupai perhitungan bunga sehingga menimbulkan persepsi negatif masyarakat terhadap lembaga keuangan syariah dan menurunkan kepercayaan masyarakat terhadap lembaga keuangan syariah.

Citra buruk lembaga keuangan syariah tentu juga akan berdampak pada persepsi masyarakat tehadap perbankan syariah yang merupakan bagian dari lembaga keuangan syariah. Penelitian yang dilakukan oleh Bank Indonesia yang berjudul Potensi, Preferensi dan Perilaku Masyarakat terhadap bank syariah di Pulau Jawa tahun 2000, mengungkapkan bahwa di wilayah Jawa Barat masyarakat non nasabah yang diberi penjelasan tentang produk/jasa Bank Syariah mempunyai kecenderungan kuat untuk memilih bank syariah. Sebaliknya, nasabah yang telah menggunakan produk/jasa bank syariah mempunyai kecenderungan untuk berhenti menjaadi 
Refgiani, et al/Jurnal Ekonomi Syariah Teori dan Terapan Vol. 3 No. 9 September 2016: 758-770; Efektivitas Pengawasan Penerapan Prinsip Syariah oleh Dewan Pengawas Syariah (DPS) (Studi Kasus pada PT. BPRS Amanah Sejahtera)

nasabah karena keraguan terhadap konsistensi penerapan prinsip syariah.

Penerapan prinsip syariah pada bank syariah selalu diawasi oleh Dewan Syariah Nasional melalui Dewan Pengawas Syariah yang ada di setiap bank syariah. Dewan Pengawas Syariah bertanggung jawab atas kesesuaian prinsip syariah pada semua produk/jasa yang ditawarkan oleh bank syariah kepada masyarakat. Tanggung jawab ini diimplementasikan pada pengawasan terhadap kegiatan operasional bank syariah. Kegiatan pengawasan pada bank syariah belum mendapatkan penilaian yang baik dari masyarakat. Berdasarkan berita di Republika Online pada hari Rabu tanggal 4 November 2015, peserta seminar "Edukasi Keuangan Syariah untuk Pengusaha" menilai praktik perbankan syariah masih lemah. Ada dua kritik mengenai praktik perbankan syariah yang disampaikan. Salah satunya adalah kritik mengenai pengawasan yang dilakukan Dewan Pengawas Syariah (DPS). Para anggota DPS dinilai belum memahami sepenuhnya konsep ekonomi syariah, sehingga kualitas pengawasan dipertanyakan (www.republika.co.id, diakses pada tanggal 04 Desember 2015).

Kritik ini perlu diperhatikan dan dijadikan pelajaran bagi perbaikan terhadap kualitas praktik perbankan syariah. Penilaian kritis ini mungkin sekali benar, tetapi sifatnya kasuistik dan kondisional. Kritikan lain terkait dengan pengawasan DPS adalah jumlah DPS dan rangkap jabatan DPS menjadi penyebab pengawasan yang dilakukan DPS tidak optimal.

Pada penelitian yang dilakukan oleh Sanusi pada tahun 2004 dengan judul Implementasi dan Efektivitas Pengawasan Dewan Pengawas Syariah terhadap Produk Perbankan Syariah menyatakan bahwa pengawasan yang dilakukan oleh DPS terhadap produkproduk Bank Muamalat Indonesia Cabang Pekanbaru, Bank Syariah Mandiri dan Bank Riaukepri Unit Usaha Syariah belum optimal karena jumlah anggota DPS tidak seimbang dengan jumlah Bank Syariah. Ketidakoptimalan pengawasan oleh DPS juga disebabkan anggota DPS banyak tugas rangkap sehingga tugas sebagai anggota DPS tidak dapat dilakukan dengan optimal.

Penelitian ini disusun untuk mengetahui sejauh mana efektivitas pengawasan yang dilakukan oleh Dewan Pengawas Syariah pada Bank Pembiayaan Rakyat Syariah Amanah Sejahtera.

\section{LANDSAN TEORI}

Efektivitas adalah ukuran dalam menilai sejauh mana kinerja yang telah dilakukan mencapai tujuan atau sasaran. Efektivitas diukur atau dilihat dari kenyataan bahwa sesuatu itu berhasil, memiliki dampak atau menjadi sebab tercapainya tujuan atau sasaran. Efektivitas merupakan unsur penting dalam mencapai tujuan dan sasaran 
Refgiani, et al/Jurnal Ekonomi Syariah Teori dan Terapan Vol. 3 No. 9 September 2016: 758-770; Efektivitas Pengawasan Penerapan Prinsip Syariah oleh Dewan Pengawas Syariah (DPS) (Studi Kasus pada PT. BPRS Amanah Sejahtera)

yang telah ditetapkan oleh sebuah organisasi. Kinerja disebut efektif bila dapat mencapai tujuan dan sasaran tersebut pada waktu yang telah ditetapkan. Pada intinya efektiviats membahas tentang cara melakukan pekerjaan yang benar dan tepat sehingga visi dan misi organisasi dapat dicapai. Menurut Agung Kurniawan dalam bukunya Transformasi Pelayanan Publik, mendefinisikan efektivitas sebagai berikut.

Efektivitas adalah
kemampuan melaksanakan
tugas, fungsi (operasi
kegiatan, program atau
misi) daripada suatu
organisasi tanpa adanya
tekanan atau ketegangan
dianatara pelaksanaannya"
(Kurniawan, 2005:109).

Pendekatan untuk mengukur efektivitas suatu organisasi dikenal ada tiga pendekatan, sebagaimana yang dikemukakan oleh Martini dan Lubis(1987:55), yang pada pokoknya adalah sebagai berikut:

1. Pendekatan Sumber

Pedekatan sumber yakni pengukuran efektivitas melalui keberhasilan memanfaatkan sumber-sumber (input) yang dibutuhkan. Suatu organisasi harus mendapatkan sumber yang dibutuhkannya dan memeliharanya agar menjadi efektif.

\section{Pendekatan Proses}

Pendekatan proses yakni pengukuran efektivitas dari pelaksanaan program atau tugas yang telah ditetapkan. Pendekatan ini fokus pada kegiatan atau kinerja internal apakah sudah sesuai dengan rencana awal atau belum dalam mencapai tujuan organisasi.

\section{Pedekatan Sasaran}

Pendekatan sasaran, yakni pengukuran efektivitas yang fokus pada keberhasilan organisasi mencapai target sesuai dengan rencana awal dantujuan organisasi.

Kontrol dan pengawasan dijelaskan dalam ajaran Islam. Penjelasan tersebut terdapat dalam nash Al-Qur'an dan hadits yang dapat dijadikan dasar dalam pengawasan bank syariah. Sebagaimana firman Allah dalam surah Al-Maidah [5] ayat 8:

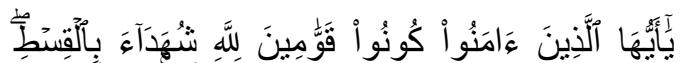

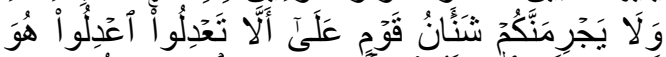

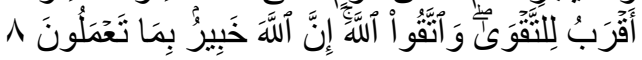

Artinya: Hai orang-orang yang beriman hendaklah kamu jadi orang-orang yang selalu menegakkan (kebenaran) karena Allah, menjadi saksi dengan adil. Dan janganlah sekali-kali kebencianmu terhadap sesuatu kaum, mendorong kamu untuk berlaku tidak adil. Berlaku adillah, karena adil itu lebih dekat kepada takwa. Dan bertakwalah kepada Allah, sesungguhnya Allah Maha Mengetahui apa yang kamu kerjakan (QS. AlMaidah 5:8).

Adapun hadits yang sesuai dengan pengawasan dan kontrol pada bank syariah salah satunya adalah hadits yang diriwayatkan Abu Sa'id Al Khudi 
Refgiani, et al/Jurnal Ekonomi Syariah Teori dan Terapan Vol. 3 No. 9 September 2016: 758-770; Efektivitas Pengawasan Penerapan Prinsip Syariah oleh Dewan Pengawas Syariah (DPS) (Studi Kasus pada PT. BPRS Amanah Sejahtera)

radiallahuanhu berkata bahwa beliau mendengar Rasulullah saw bersabda:

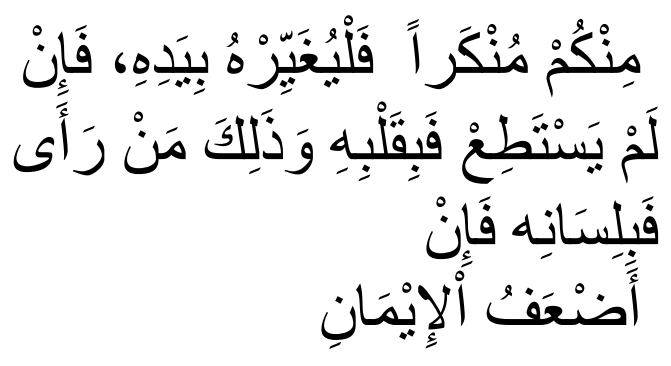

\begin{abstract}
"Barangsiapa diantaramu melihat kemungkaran, hendaklah ia mengubahnya dengan tangan (kekuasaan)-nya. Apabila tidak sanggup, dengan ucapannya. Apabila tidak sanggup, dengan hatinya, dan itulah selemahlemahnya iman" (HR. Muslim).
\end{abstract}

Ayat dan hadits di atas menerangkan bahwa kaum Mukmin diperintahkan menegakkan kebenaran dan mencegah kemungkaran. Saat menegakkan kebenaran, kaum Mukmin harus bersikap adil tanpa membedabedakan. Begitu juga dalam pengawasan pada bank syariah yakni dalam melakuakan pengawasan hendaknya bertujuan untuk mencegah kemungkaran dan senantiasa berlaku adil. Pengawasan bank syariah menuntut adanya independensi. Independensi ini bertujuan agar pengawasan yang dilakukan dapat berjalan optimal dan tidak ada campur tangan pihak lain yang dapat menimbulkan ketidakadilan.

Pengawasan pada Bank Syariah maupun Bank Pembiayaan Rakyat Syariah terdiri dari dua sistem pengawasan, yakni sistem pengawasan internal dan sistem pengawasan eksternal. Pengawasan eksternal adalah pengawasan yang dilakukan oleh pihak dari luar perusahaan, misalnya OJK, akuntan publik (termasuk external syariah auditor), DSN, dan stakeholders. Pengawasan internal adalah pengawasan yang dilakukan oleh pihak dari dalam perusahaan, misalnya internal auditor, Dewan Pengawas Syariah (DPS), Direktur Kepatuhan, Dewan Komisaris dan lain sebagainya.

Dewan Pengawas Syariah (DPS) bertugas mengawasi segala aktivitas bank agar selalu sesuai dengan prinsip-prinsip syariah. Dengan kata lain, DPS bertanggung jawab atas produk dan jasa yang ditawarkan kepada masyarakat agar sesuai dengan prinsip syariah. Selain itu, investasi atau proyek yang ditangani oleh bank juga harus sesuai dengan prinsip syariah, dan tentu saja bank itu sendiri harus dikelola sesuai dengan prinsip syariah.

Berdasarkan Surat Edaran Bank Indonesia (SEBI) No.8/19/DPbS tahun 2006 perihal Pedoman Pengawasan Syariah dan Tata Cara Pelaporan Hasil Pengawasan Bagi Dewan Pengawas Syariah, Dewan Pengawas Syariah (DPS) adalah "...dewan yang melakukan pengawasan terhadap prinsip syariah dalam kegiatan usaha bank syariah yang dalam menjalankan fungsinya bertindak secara independen". Bank Indonesia selanjutnya menetapkan bahwa keanggotaan DPS harus mendapatkan rekomendasi dari DSN dan Majelis Ulama 
Refgiani, et al/Jurnal Ekonomi Syariah Teori dan Terapan Vol. 3 No. 9 September 2016: 758-770; Efektivitas Pengawasan Penerapan Prinsip Syariah oleh Dewan Pengawas Syariah (DPS) (Studi Kasus pada PT. BPRS Amanah Sejahtera)

Indonesia.

Pengawasan penerapan prinsip syariah oleh Dewan Pengawas Syariah (DPS) memiliki pedoman yang telah diatur oleh Bank Indonesia, yakni Surat Edaran Bank Indonesia No 15/22/DPbS tahun 2013. SEBI No 15/22/DPbS merupakan surat edaran yang dikeluarkan oleh Bank Indonesia dengan tujuan untuk memberi pedoman kepada Dewan Pengawas Syariah (DPS) Bank Pembiayaan Rakyat Syariah dalam melaksanakan tugas, wewenang dan tanggung jawab. Aturan pada SEBI No 15/22/DPbS ini menjadi standar baku bagi pengawasan prinsip syariah oleh DPS Bank Pembiayaan Rakyat Syariah.

\section{METODE PENELITIAN}

\section{Pendekatan Penelitian}

Pendekatan yang digunakan dalam penelitian ini adalah pendektan kualitatif. Metode penelitian yang digunakan adalah studi kasus.

\section{Ruang Lingkup Penelitian}

Pembatasan penelitian perlu dilakukan agar hasil pembahasan dapat mencapai sasaran, terfokus, dan dapat menjawab rumusan masalah. Oleh karena itu penelitian ini dibatasi dan terfokus pada efektivitas pengawasan oleh DPS pada PT. BPRS Amanah Sejahtera. Pengukuran efektivitas dilakukan dengan membandingkan pengawasan oleh DPS PT. BPRS Amanah Sejahtera dengan SEBI No 15/22/DPbS tahun 2013.

\section{Jenis dan Sumber Data}

Jenis data yang dibutuhkan dalam penelitian ini adalah data primer Idan data sekunder. Data primer merupakan data yang diperoleh secara langsung dari lokasi penelitian. Data sekunder yaitu data dokumen-dokumen pendukung yang terkait dengan pengawasan oleh Dewan Pengawas Syariah. Sumber data pada penelitian ini diperoleh dari literature review dan data-data lapangan.

\section{Teknik Pemeriksaan Keabsahan Data}

Data-data yang diperoleh dari berbagai sumber diperlukan pengecekan lebih lanjut untuk memenuhi syarat objektivitas dan kredibilitas, yaitu melalui proses triangulasi dengan sumber. Penelitian ini akan membandingkan keselarasan antara wawancara dengan pihak terkait, observasi di lapangan, dan dibuktikan dengan arsip dokumen yang ada, sehingga data dapat akurat dan dapat dipertanggungjawabkan.

\section{Teknik Analisis Data}

Data-data yang diperoleh dari berbagai sumber diperlukan pengecekan lebih lanjut untuk memenuhi syarat objektivitas dan kredibilitas, yaitu melalui proses triangulasi dengan sumber. Teknik analisis data menggunakan teknik penjodohan pola, yakni dengan membandingkan pengawasan yang dilakukan oleh DPS BPRS Amanah Sejahtera dengan SEBI No 15/22/DPbS tahun 2013. 
Refgiani, et al/Jurnal Ekonomi Syariah Teori dan Terapan Vol. 3 No. 9 September 2016: 758-770; Efektivitas Pengawasan Penerapan Prinsip Syariah oleh Dewan Pengawas Syariah (DPS) (Studi Kasus pada PT. BPRS Amanah Sejahtera)

\section{HASIL DAN PEMBAHASAN}

PT. BPRS Amanah Sejahtera merupakan bank pembiayaan rakyat syariah yang menjalankan usahanya dengan prinsip syariah Islam dalam menghimpun dana maupun menyalurkan dana dalam bentuk pembiayaan kepada para pengusaha kecil dan menengah. Sebagai bank pembiayaan rakyat syariah, BPRS Amanah Sejahtera memiliki Dewan Pengawas Syariah (DPS) yang bertugas mengawasi kegiatan BPRS Amanah Sejahtera agar sesuai dengan prinsip syariah. Kegiatan pengawasan yang dilakukan oleh DPS, yang pertama adalah pengawasan terhadap produk dan aktivitas baru pada bank pembiayaan rakyat syariah. Ada beberapa hal yang dilakukan DPS dalam pengawasan produk dan aktivitas baru BPRS Amanah Sejahtera, yaitu:

1. Meminta penjelasan dari pejabat BPRS yang berwenang mengenai tujuan, karakteristik, dan fatwa dan/atau akad yang digunakan sebagai dasar dalam rencana penerbitan produk dan aktivitas baru. Berdasarkan hasil wawancara dengan ketiga informan didapat keterangan sebagai berikut. Dalam setiap pengajuan produk baru oleh BPRS, DPS BPRS Amanah Sejahtera mengadakan pertemuan dengan Direksi dan Divisi yang mengusulkan produk tersebut. Pada rapat tersebut DPS meminta penjelasan terkait tujuan produk, akad produk dan karakteristiknya. Divisi yang mengusulkan produk tersebut kemudian mempresentasikan usulannya di depan DPS dan Direksi.

2. Memeriksa fatwa dan/atau akad yang digunakan dalam produk dan aktivitas baru. Dalam hal produk dan aktivitas baru belum didukung dengan fatwa dan/atau akad dari DSN-MUI maka DPS mengusulkan kepada Direksi BPRS untuk meminta fatwa kepada DSN-MUI. Hasil wawancara menerangkan bahwa selama ini produk baru yang diusulkan telah memiliki fatwa dari DSN-MUI, sehingga DPS tidak perlu mengusulkan kepada Direksi BPRS untuk meminta fatwa kepada DSN-MUI.

3. Mengkaji fitur, mekanisme, persyaratan, ketentuan, sistem dan prosedur produk dan aktivitas baru terkait dengan pemenuhan prinsip syariah. Dari penjabaran wawancara terkait pengawasan produk baru dan aktivitas baru dapat kita lihat bahwa DPS mengkaji mekanisme, fitur, ketentuan, system dan prosedur pada produk baru. Pada produk baru Wa'd misalnya, DPS mengkaji makanisme produk yang mewajibkan nasabah mengambil seluruh dana yang telah dijanjikan oleh BPRS. Mekanisme tersebut mengandung unsur pemaksaan bagi nasabah. Pemaksaan dapat menjadi perbuatan zjalim, sehingga ketentuan tersebut dihapus. 
Refgiani, et al/Jurnal Ekonomi Syariah Teori dan Terapan Vol. 3 No. 9 September 2016: 758-770; Efektivitas Pengawasan Penerapan Prinsip Syariah oleh Dewan Pengawas Syariah (DPS) (Studi Kasus pada PT. BPRS Amanah Sejahtera)

4. Memberikan pendapat terkait aspek pemenuhan prinsip syariah atas produk dan aktivitas baru yang akan dikeluarkan. Pendapat DPS terkait pemenuhan prinsip syariah dapat dilihat pada pengawasan produk baru BPRS, yaitu Wa'd. DPS memberikan pendapatnya yaitu menghilangkan ketentuan bahwa nasabah wajib menggunakan dana seluruhnya yang telah dijanjikan BPRS. Karena dikhawatirkan ketentuan tersebut mengarah pada perbuatan pemaksaan dan z\}alim.

5. Menjelaskan secara mendalam dan holistik mengenai pemenuhan prinsip syariah atas produk dan aktivitas baru yang dikembangkan oleh BPRS. Penjelasan secara mendalam dan holistik mengenai pemenuhan prinsip syariah atas produk dan aktivitas baru selalu dilakukan oleh DPS BPRS Amanah Sejahtera. Penjelasan ini dilakukan saat diskusi bersama Direksi dan juga divisi yang mengusulkan produk baru. Penjelasan yang diberikan oleh DPS biasanya disertai pendapat dan saran terhadap produk baru tersebut

Selanjutnya, kegiatan pengawasan oleh DPS yang kedua adalah pengawasan terhadap kegiatan penghimpunan dana, pembiayaan dan kegiatan jasa BPRS lainnya. Dalam pengawasan tersebut, DPS melakukan beberapa hal, sebagai berikut:
1. Melakukan pemeriksaan di kantor BPRS paling kurang (satu) kali dalam 1 (satu) bulan. Dari keterangan yang diberikan oleh para informan, DPS BPRS Amanah Sejahtera melakukan kunjungan satu kali setiap bulan. Namun, bila ada masalah yang mendesak, DPS bersedia datang kembali ke kantor BPRS Amanah Sejahtera.

2. Meminta laporan kepada Direksi BPRS mengenai produk dan aktivitas penghimpunan dana, pembiayaan dan kegiatan jasa BPRS lainnya yang dilakukan oleh BPRS. Pengawasan terhadap kegiatan penghimpunan dana, pembiayaan dan kegiatan BPRS lainnya dilakukan oleh DPS dengan meminta berkas dan mengoreksi akadnya. DPS mengoreksi akad di depan Direksi dan meminta penjelasan terkait akd tersebut kepada Direksi.

3. Melakukan pemeriksaan secara uji petik (sampling) paling kurang sebanyak tiga nasabah untuk masingmasing produk dan/atau akad penghimpunan dana, pembiayaan dan kegiatan jasa lainnya, termasuk penanganan pembiayaan yang direstrukturisasi oleh BPRS. Berdasarkan keterangan dari informasi pertama, DPS BPRS Amanah Sejahtera dalam melakukan pengawasan menggunakan metode sampling. DPS memeriksa berkas dari tiga nasabah terbesar di setiap kantor cabang BPRS 
Refgiani, et al/Jurnal Ekonomi Syariah Teori dan Terapan Vol. 3 No. 9 September 2016: 758-770; Efektivitas Pengawasan Penerapan Prinsip Syariah oleh Dewan Pengawas Syariah (DPS) (Studi Kasus pada PT. BPRS Amanah Sejahtera)

Amanah Sejahtera. Begitu juga dengan keterangan yang diberikan oleh informan kedua bahwa setiap divisi yang memberi laporan ke DPS menggunakan metode sampling data, jadi tidak semua data ditampilkan melainkan hanya beberapa untuk mewakili data keseluruhan.

4. Memeriksa dokumen transaksi dari nasabah yang ditetapkan sebagai sampel untuk mengetahui pemenuhan prinsip syariah. Berdasarkan keterangan para informan, DPS BPRS Amanah Sejahtera meminta berkas-berkas nasabah untuk mengoreksi akad. Artinya, dalam mengoreksi akad, DPS melihat proses transaksi antara nasabah dengan BPRS. Proses transaksi ini meliputi persyaratan yang harus dipenuhi, kesepakatan bagi hasil, kesepakatan penetapan margin, penetapan dan pembebanan ujrah serta kewajiban dan hak nasabah dan BPRS.

5. Melakukan inspeksi, pengamatan, permintaan keterangan dan/atau konfirmasi kepada pegawai BPRS dan/atau nasabah untuk memperkuat hasil pemeriksaan dokumen sebagaimana dimaksud dalam poin 4 , apabila diperlukan. Sistem pengawasan yang dilakukan oleh DPS BPRS Amanah Sejahtera adalah mengoreksi akad di depan para Direksi dan beberapa karyawan. Poin kelima ini sudah sesuai dengan pengawasan yang dilakukan oleh DPS di BPRS Amanah Sejahtera. DPS meminta penjelasan lebih lanjut kepada Direksi maupun karyawan yang hadir dalam memeriksa akad.

6. Memberikan pendapat terkait aspek pemenuhan Prinsip Syariah atas:

a. kegiatan penghimpunan dana, pembiayaan dan jasa BPRS lainnya, dan

b. perhitungan dan pencatatan transaksi keuangan mengenai pembayaran bonus atau bagi hasil kepada nasabah penyimpan, pembayaran bagi hasil kepada bank lain, pengakuan pendapatan yang berasal dari pengenaan denda, penempatan pada bank konvensional, dan pendapatan non halal lainnya, serta pelaporan penerimaan dana dari zakat, infak, dan sedekah.

DPS BPRS Amanah Sejahtera dalam melakukan pengawasan telah memenuhi poin ini. Berdasarkan keterangan yang diberikan oleh para informan di atas, DPS pernah memberikan pendapat terkait aspek pemenuhan prinsip syariah dalam penghimpunan dana. BPRS Amanah Sejahtera membebankan biaya administrasi pada nasabah tabungannya. DPS yang mengetahui akan hal ini memberikan pendapat bahwa hal tersebut tidak sesuai dengan prinsip syariah pada fatwa DSN No 02/DSN-MUI/IV/2000. Pada 
Refgiani, et al/Jurnal Ekonomi Syariah Teori dan Terapan Vol. 3 No. 9 September 2016: 758-770; Efektivitas Pengawasan Penerapan Prinsip Syariah oleh Dewan Pengawas Syariah (DPS) (Studi Kasus pada PT. BPRS Amanah Sejahtera)

fatwa tersebut terdapat ketentuan yang berbunyi, "Bank sebagai mudharib menutup biaya operasioanl tabungan dengan menggunakan nisbah keuntungan yang menjadi haknya". Kemudian DPS juga memberi pendapatnya terkait pencatatan pendapatan.

7. Melakukan pembahasan dengan BPRS mengenai hasil temuan pengawasan penerapan Prinsip Syariah sebagaimana dimaksud dalam poin 1 yang hasilnya dituangkan dalam risalah rapat. Dalam mengoreksi akad, DPS tidak melakukannya sendiri di dalam ruang kerja melainkan dengan sistem diskusi bersama Direksi, kepala bagian dan manajer. Hasil pemeriksaanpun langsung disampaikan kepada Direksi, kepala bagian dan manajer. Bila ditemukan akad yang tidak sesuai dengan prinsip syariah maka akad tersebut direvisi pada waktu itu juga.

8. Menyusun laporan hasil pengawasan penerapan Prinsip Syariah atas kegiatan usaha BPRS. DPS menuyusun laporan dua kali dalam setahun untuk laporan semesteran ke Bank Indonesia. DPS membuat laporan sesuai dengan format yang diberikan oleh Bank Indonesia. Dalam menyusun laporan ini DPS menyampaikan hasil pemeriksaannya termasuk temuantemuan dan perbaikan atas akad, kegiatan penghimpunan dana, pembiaayaan, dan produk jasa BPRS lainnya.

9. Menjelaskan secara mendalam dan holistik mengenai hasil pengawasan penerapan Prinsip Syariah kepada Otoritas Jasa Keuangan (OJK), termasuk dalam pembahasan exit meeting hasil pemeriksaan Bank Indonesia. Penyampaian laporan ke Bank Indonesia disusun DPS secara jelas sesuai dengan hasil pemeriksaan yang telah dilakukan. Hasil rapat dengan Direksi BPRSpun dilaporkan ke Bank Indonesia berikut bukti-bukti dokumentasi

Pengawasan penerapan prinsip syariah yang dilakukan oleh DPS secara umum telah memenuhi pedoman yang terdapat pada SEBI No. 15/22/DPbS tahun 2013. Hanya satu poin yang tidak dipenuhi oleh DPS BPRS Amanah Sejahtera, yaitu poin yang menjelaskan DPS meminta bukti dokumen berupa perhitungan dan pengbayaran bagi hasil atau bonus, pembayaran bagi hasil pada bank lain, pencatatan dan pengakuan pendapat serta pencatatan dan pelaporan penrimaan dan ZIS.

Meskipun demikian, DPS memberi saran dan nasehat terkait hal-hal yang disebutkan pada poin tersebut. Misalnya, DPS menyarankan bank untuk tidak memberikan bonus yang terlalu sedikit. Contoh lain, DPS memberikan saran untuk tidak memasukkan fee dari asuransi ke dalam pos pendapatan. Hal ini karena bila fee masuk pos pendapatan dan fee 
Refgiani, et al/Jurnal Ekonomi Syariah Teori dan Terapan Vol. 3 No. 9 September 2016: 758-770; Efektivitas Pengawasan Penerapan Prinsip Syariah oleh Dewan Pengawas Syariah (DPS) (Studi Kasus pada PT. BPRS Amanah Sejahtera)

tidak dibayarkan oleh asuransi, maka bank tidak dapat menepati bagi hasil yang telah disepakati dengan nasabah. Dalam hal ini bank telah berlaku zallim pada nasabah.

\section{SIMPULAN DAN SARAN}

\section{Simpulan}

Berdasarkan pembahasan yang telah dijelaskan di atas, pengawasan penerapan prinsip syariah dinilai telah efektif oleh informan. Hal ini karena para informan memiliki pertimbangan lain dalam menilai efektivitas pengawasan oleh DPS. Pertimbangan dalam menilai pengawasan DPS adalah:

1. DPS telah melakukan pengawasan, pemeriksaan dan pembinaan dengan baik. Menurut Komaruddin (1994:104), "Pengawasan adalah berhubungan dengan perbandingan antara pelaksanaan actual, rencana, dan awal untuk langkah perbaikan terhadap penyimpangan dan rencana yang berarti". Jadi, pengawasan tidak hanya dilakukan dengan memeriksa berkas dengan ketentuan yang ada tapi juga diperlukan perbaikan. DPS BPRS Amanah Sejahtera melakukan perbaikan dengan membina para karyawan. Pembinaan ini bertujuan agar para karyawan lebih paham mengenai penerapam prinsip syariah dalam perbankan. Bila karyawan telah memahami maka penyimpangan prinsip syariah pun dapat dikurangi bahkan dihindari.

2. DPS mejalankan pengawasan dengan kemampuan terbaiknya. DPS sebagai seorang muslim merasa bahwa sesama muslim harus saling menasehati dalam hal kebaikan. Sebagaimana firman Allah dalam QS. Al-Ashr [103] ayat 1-3 yang berbunyi:

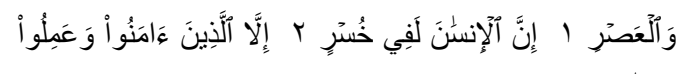

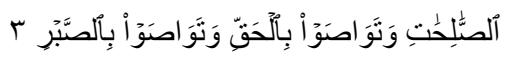

Artinya: Demi masa. Sesungguhnya manusia itu benar-benar dalam kerugian. Kecuali orangorang yang beriman dan mengerjakan amal saleh dan nasehat menasehati supaya mentaati kebenaran dan nasehat menasehati supaya menetapi kesabaran (QS. Al-Ashr 103:1-3).

Sebagai seorang pengawas, DPS BPRS Amanah Sejahtera telah berpedoman pada ajaran Islam dalam melaksanakan pengawasan. DPS menjadikan ajaran Islam sebagai dasar dan motivasinya melaksanakan pengawasan penerapan prinsip syariah di BPRS Amanah Sejahtera.

3. DPS memberikan prioritas kepada BPRS Amanah Sejahtera dan memberikan kemudahan dalam komunikasi. DPS membuka akses komunikasi yang luas dengan BPRS, yaitu tidak hanya dengan bertemu langsung tapi juga dengan berbagai media seperti sms, chating ataupun email. 
Refgiani, et al/Jurnal Ekonomi Syariah Teori dan Terapan Vol. 3 No. 9 September 2016: 758-770; Efektivitas Pengawasan Penerapan Prinsip Syariah oleh Dewan Pengawas Syariah (DPS) (Studi Kasus pada PT. BPRS Amanah Sejahtera)

\section{Saran}

1. BPRS Amanah Sejahtera lebih meningkatkan pemahaman karyawannya terhadap penerapan prinsip syariah agar penyimpangan penerpan prinsip syariah dapat dihindarkan. Dalam hal ini, pembinaan bagi karyawan sebaiknya dijadwalkan secara rutin.

2. BPRS Amanah Sejahtera agar mempertahankan hubungan baik dengan Dewan Pengawas Syariah (DPS) agar efektivitas pengawasan oleh DPS dapat dipertahankan dan ditingkatkan.

3. DPS agar mempertahankan peran yang telah dilaksanakan dengan baik.

4. Untuk penelitian selanjutnya, diharapkan penelitian ini dapat dijadikan acuan untuk melakukan penelitian terkait dengan pengawasan oleh DPS. Penelitian selanjutnya dapat mengukur efektivitas pengawasan DPS pada Bank Syariah di Indonesia.

\section{DAFTAR PUSTAKA}

Al-Qur'an Karim.

Al-Qur'an dan terjemahan. 2010. AlHikmah. Bandung: CV Penerbit Diponegoro.

Antonio, M. Syafi'I. 2007. Bank Syariah: Dari Teori ke Praktek. Jakarta: Gema Insani Press.

Alwi, Syafaruddin. 2014. Kompetensi Dewan Pengawas Syariah. E-Paper,
(Online), (http://www.republika.co.id, diakses 04 Desember 2015).

"Bank Amanah Sejahtera". www.amanahsejahtera.com diakses pada tanggal 27 Desember 2015. Pukul 19.00 WIB.

Bank Indonesia. 2000. Potensi, Preferensi dan Perilaku Masyarakat terhadap Bank Syariah di Pulau Jawa. Direktorat Penelitian dan Pengaturan Perbankan: Jakarta.

Jahra, Patimatu. 2002. Profil Usaha BMT Ukhuwah di Kota Banjarmasin. Tesis MSI UII Yogyakarta.

Karim, Adiwarman A. 2010. Bank Islam Analisis Fiqih dan Kevangan. Edisi Ketiga. Jakarta: PT. Raja Grafindo Persada.

Kurniawan, Agung. 2005. Transformasi Pelayanan Publik. Yogyakarta: Pembaruan

Martini dan Lubis. 1987. Teori Organisasi. Bandung: Ghalia Indonesia

Mu'allim, Amir. "Persepsi Masyarakat Terhadap Lembaga Keuangan Syariah". Al-Mawardi Edisi X, thn 2003. Yogyakarta, Indonesia.

Moleong, Lexy J. 2001. Metodologi Penelitian Kualitatif. PT Remaja Rosdakarya: Bandung.

Otoritas Jasa Keuangan. 2013. Surat Edaran No 15/22/DPbS Tahun 2013 Perihal Pedoman Pelaksanaan Tugas dan Tanggung Jawab Dewan Pengawas Syariah Bank Pembiayaan Rakyat Syariah. Jakarta: Bank Indonesia. 
Refgiani, et al/Jurnal Ekonomi Syariah Teori dan Terapan Vol. 3 No. 9 September 2016: 758-770; Efektivitas Pengawasan Penerapan Prinsip Syariah oleh Dewan Pengawas Syariah (DPS) (Studi Kasus pada PT. BPRS Amanah Sejahtera)

Sanusi. 2004. Implementasi dan Efektivitas

Pengawasan Dewan Pengawas

Syariah terhadap Produk Perbankan

Syariah (Analisis Perbandingan

Pengawasan pada Bank Muamalat

Indonesia, Bank Syariah Mandiri dan

Bank riaukepri Unit Usaha Syariah

terhadap Produk Bank Syariah).

Disertasi. UIN Suska Riau. Pekanbaru.

"Sekilas Perbankan Syariah di Indonesia".

http://www.bi.go.id/id/perbankan/syari

ah/Contents/Default.aspx diunduh

pada tanggal 22 Agustus 2015. Pukul

13.00 WIB.

Solihin. 1999. Perilaku Konsumen terhadap

Produk BMT (Studi Kasus di BMT

Kharisma Magelang Jawa Tengah).

Tesis MSI UII. Yoyakarta.

Yin, Robert K. 2003. Case Study Research.

Third Edition. London: Sage Publications

Ltd. 